\title{
PLANNING THE OUTSOURCING SYSTEM TO IMPROVE PERFORMANCE OF CV HK MOJOKERTO COMPANY
}

\author{
Sukowijoyo Natanael ${ }^{*}$, Herdinata Christian \\ Faculty of Management and Business, University of Ciputra, Surabaya, Indonesia \\ *E-mail: natanael.sukowijoyo@gmail.com \\ ORCID: 0000-0001-7791-487X
}

\begin{abstract}
Productivity is the main key for manufacturing companies, especially for nail companies that have very low profit margins. Labor performance greatly influences the results that a company will obtain. If laborers produce substandard production, the company cannot run optimally. This study aims to design an outsourcing system that will replace the current old system run by CV HK Mojokerto. This study applies a qualitative approach. Data collection technique carried out in this study is semi-structured interviews with 3 speakers from the company's internal and 2 speakers from the experts. The interview results will be tested using the triangulation method. Based on the analysis results that have been obtained, it forms a framework for planning outsourcing system that can improve the company performance of CV HK Mojokerto. The outsourcing system is chosen because the packing work is not the company's core business. Therefore, it does not really need labors with high competence since it is more concerned with efficiency, neatness and speed. In the cost analysis stage, the company compares the cost of outsourcing system with the old system. It is concluded that the selection of outsourcing system has made the company only pay labor costs that are in accordance with productivity and the cost of insurance costs of IDR 15,000 per labor per month.
\end{abstract}

\section{KEY WORDS}

Nail company, labor, outsourcing, productivity.

In this globalization era, competition between goods and services companies is getting tighter. All companies are competing to provide high-quality services and products so that customers increase and companies get high profits. Similarly, companies in Indonesia from time to time continue to develop and improve the quality of their products through increasing human resources. Human resources are the only resources that have a sense of mind, desire, skill, knowledge, encouragement, power, and work. All potential human resources affect the efforts of an organization in achieving its goals. Despite of technological progress, information development, and the availability of capital and materials, it is difficult for an organization to achieve its goals without human resources (Sutrisno, 2009).

Every company has a vision, missions, and goals that it wants to achieve. The achievement of these goals is determined by the human resource management who runs them. Human resources in the business strategic of a company generally consist of three parts that have different labor statuses. It consists of permanent employees, employees under work agreements for a certain time (contract employees), and outsourcing employees.

Tighter competition also requires companies to be more flexible in responding to market demands. Outsourcing strategy is one form of flexibility that needs to be considered. The use of outsourcing labor in developed and developing countries is a reasonable company policy and indeed must be carried out. It is due to the size of the company and the many types of jobs that certainly require many types of expertise. Thus, it is not possible for a company to provide labor as a whole.

Kremic et al (2006) stated that over the past ten years, there has been an evolution in the outsourcing process from traditional to strategic way. Traditionally, it relates to supporting activities such as cleaning, catering, security, and the like that do not require special 
competencies from suppliers. Furthermore, it develops towards strategic activity when the outsourcer hands over some of its main activities to the vendor.

Indrajit \& Djokopranoto (2004) explained that in general companies choose to outsource routine work that is less strategic. Outsourcing services do non-core business work. Meanwhile, core business work which is also the core competence of a company is still carried out on its own.

The motive for companies to carry out outsourcing strategies is to get cost benefits (efficiency), access to innovation, and a greater focus on core competencies that the company has (Pratap, 2014). Elmuti (2003) added that there are five main factors that influence a company's success in implementing an outsourcing project consisting of clear objectives and expectations of outsourcing activities, the right choice of outsourcing partners, adequate skills to negotiate contracts, good planning at all stages of outsourcing, and effective organizational communication.

CV HK Mojokerto is a company engaged in manufacturing with the main products of nails. The company's main products are wood nails with several variants including Plywood nails, Seri nails, Kalsi board nails, and Ship nails. The wood nails are produced through several stages of the process as presented in Appendix 2. The production process starts from supplying raw materials, drawing process, and then cutting and frying. The results of nail frying are then examined through Quality Control stage. If the product meets the qualifications, it will become a finished product. Furthermore, the nail products go to the packing process, are stored in the warehouse, and then they are ready to be distributed to customers.

Based on the researchers' evaluation results in the field, the company assessed that workers had not carried out their work optimally. It was proven that the packing results of the nail products of Chrome, CSB, Plywood, and Seri types were still not reaching the target. The company sets packing targets for each shift of 1,350 for Chrome products, 630 for CSB products, and 900 for Plywood and Seri products. During June 2018, it was found that the realization of packing results per shift still had not reached the set target. It shows that the packing division labor productivity is still not optimal.

The cause of labors not working optimally is the lack of initiative to immediately complete or make a report when they experience obstacles in their work. It might be caused by the salary system that the company applies. Currently, the company applies a daily salary system. By implementing this system, labors will get the same salary amount regardless how much work they have done. Thus, it causes labors to be less active in working, often lazing because they get the same salary; no matter how much results they produce every day.

Implementation of the outsourcing system is expected to improve employee performance and cost efficiency. Cost efficiencies that can be done due to the implementation of outsourcing systems include salary costs that are adjusted to productivity, no premiums on BPJS Kesehatan (Social Security Administrator for Health) or BPJS Ketenagakerjaan (Social Security Administrator for Employee), no pension fees or Old Age Guarantees, there are no meal costs, and there are no fees for holiday allowances.

\section{METHODS OF RESEARCH}

This research applies descriptive qualitative approach. According to Moleong (2010), a descriptive approach is a method that aims to examine the status of a group of people, an object, a set of conditions, a system of thought, or a class of events in the present. Meanwhile, qualitative research is intended to understand the phenomenon of what is experienced by the research subject such as behavior, perceptions, motivations, actions, etc. in a holistic and descriptive manner in the form of words and language, in a specific natural context and by utilizing various natural methods. This study will describe and analyze the design of the implementation of outsourcing systems in improving the company performance of CV HK Mojokerto.

Data collection technique carried out in this study is semi-structured interviews with pre-determined informants to obtain the information that the researchers need. According to 
Sugiyono (2013), semi-structured interviews are a type of interview in the category of indepth interviews where the informants invited to discuss will feel more comfortable, free, and open to the types of questions the researchers give.

Data analysis is the process of systematically finding and compiling data obtained from interviews, field notes, and documentation by organizing data into several categories, describing it into units, synthesizing, arranging into patterns, choosing which ones are important and which will be studied, and drawing conclusions so that the data is easily understood by the researchers themselves and others (Sugiyono, 2013). In this study, data analysis technique applies qualitative analysis with the model approach proposed by Miles and Huberman (2005), as follows: Data Reduction; Data Display; Verification (Conclusion Drawing).

\section{RESULTS AND DISCUSSION}

CV HK Mojokerto's Motive in Implementing an Outsourcing System. CV HK Mojokerto currently has approximately 600 employees consisting of 50 permanent employees and 550 contract employees. In this case, the salary system for contract employees is based on the number of their working days. In the packing section itself, there are 150 employees who are all contract employees who are paid daily; with the distribution of 120 people working on nail packing and the remaining 30 people on wire packing. Contract employees are paid daily for whatever quantity they produce. As long as they enter work, the salary earned by the labors will be the same.

Currently, the company needs an outsourcing system because the current increase in regional minimum wages is no longer in line with the performance in the field which results in higher production costs. In addition, the company assessed that workers had not carried out their work optimally. It was proven that the packing results of the nail products of Chrome, CSB, Plywood, and Seri types were still not reaching the target. The company sets packing targets for each shift of 1,350 for Chrome products, 630 for CSB products, and 900 for Plywood and Seri products. During June 2018, it was found that the realization of packing results per shift still had not reached the set target; Chrome products were still less than 285 $\mathrm{kg}$, CSB products were still less than $174 \mathrm{~kg}$, and Plywood and Seri products were still less than $135 \mathrm{~kg}$.

The realization of work that still does not reach the target is caused by the lack of initiative to immediately complete or make a report when the labors experience obstacles in their work. Currently, the company applies a daily salary system. By implementing this system, labors will get the same salary amount regardless how much work they have done. Thus, it causes labors to be less active in working, often lazing because they get the same salary; no matter how much results they produce every day. This condition causes the achievement of targets not to be realized.

Through the implementation of an outsourcing system, it is expected that labors will work more actively so that the achievement of targets can increase. The application of this system is intended to provide motivation to workers, which with the increasing quantity of work produced, the more wages they will get. The challenge is the quality control of packing results that must remain in accordance with the standards. It is not only completing the work or achieving the pre-determined quantity, but also considering the quality.

Division Determination. Currently, the divisions in the company consist of raw material, production, packing, logistics, warehouse, admin, HRD, and finance divisions. Nearly all labors in each division use a contract system, for which payment of salary uses a daily calculation system. It means that the labors are paid as much as their working days.

Before choosing an outsourcing strategy, the company is actually faced with three choices of strategies which include adding labors, automation to the machine, and the outsourcing system itself. These three strategies can be carried out by the company to improve the labor performance of packing division with several advantages and disadvantages. 
The strategy of adding labors has the advantage that the existing HR management system in the company does not change in which the management only continues the labor management system that has been implemented previously. However, this method has a weakness in terms of costs, because with the increasing number of labors, the company's expenditure for salary posts will be even greater. Furthermore, the automation method can also be carried out to improve the performance of the packing division. This method has advantages in terms of efficiency for a long period of time because the production process will be faster.

Division selection criteria:

1. Not the company's core competency;

2. The labor costs that can be minimized the most;

3. The easiest transfer of labor;

4. The skills needed are not difficult;

5. Functions that do not have much impact on the company's operations.

Based on the division criteria above, the choice of division to be outsourced is the packing division. The reason for choosing the packing division compared to other divisions is because the division has the most labors. Thus, the impact of cost savings and productivity impacts is greater than other divisions. In addition to the transition time needed is relatively short; it also does not require skills that are too high. Based on these conclusions, the packing division was chosen as the division to be handed over to the outsourcing party.

Design of the Outsourcing System Implementation at CV HK Mojokerto. The design of the system implementation is based on previous research which has 7 factors that must be considered. These factors do not have to be applied or followed sequentially but they can also be carried out according to the common norms.

At this stage, the company needs to set a target and the result of packing costs after using outsourcing labors. The results expected by the company are calculated based on historical data from the highest results of division packing during 2017-2018 as follows:

Table 1 - Achievement Targets of Outsourcing Labors

\begin{tabular}{|c|c|c|c|c|}
\hline \multirow{2}{*}{ Product Type } & \multirow{2}{*}{ Current Labor Work Results } & \multicolumn{3}{|c|}{ Target of Outsourcing Worker Per Day } \\
\cline { 3 - 5 } & & Month 1 and 2 & Month 3 and 4 & Month 5 onwards \\
\hline Chrome & 1,065 & 950 & 1,150 & 1,350 \\
\hline CSB & 456 & 430 & 530 & 630 \\
\hline Plywood and Seri & 765 & 600 & 750 & 900 \\
\hline
\end{tabular}

Source: CV HK Mojokerto.

Table 2 - Current Composition of Labor Cost in Packing Division

\begin{tabular}{|c|c|c|c|}
\hline \multirow{2}{*}{$\mathrm{n} / \mathrm{n}$} & \multicolumn{3}{|c|}{ Current Condition } \\
\cline { 2 - 4 } & Chrome & CSB & Plywood and Seri \\
\hline Labor Salary/ Month & IDR 4,537,283 & IDR 4,537,283 & IDR 4,537,283 \\
\hline Labor Salary/ Day & IDR 181,491 & IDR 181,491 & IDR 181,491 \\
\hline Average Packing Ability & 1,065 & 465 & 765 \\
\hline Packing Labor Cost/ Kg & IDR 170 & IDR 390 & IDR 237 \\
\hline
\end{tabular}

Source: Processed Data.

Table 3 - Needs for Number of Labors

\begin{tabular}{|c|c|c|c|c|c|}
\hline \multicolumn{2}{|c|}{$\mathrm{n} / \mathrm{n}$} & \multicolumn{2}{c|}{ Current Condition } & \multicolumn{2}{c|}{ Outsourcing Target } \\
\hline Nail Type & $\begin{array}{c}\text { Production } \\
\text { Capacity/ Day (Kg) }\end{array}$ & $\begin{array}{c}\text { Packing } \\
\text { Capacity/ } \\
\text { Person }\end{array}$ & $\begin{array}{c}\text { Number of } \\
\text { People Needed }\end{array}$ & $\begin{array}{c}\text { Packing } \\
\text { Capacity/ } \\
\text { Person }\end{array}$ & $\begin{array}{c}\text { Number of } \\
\text { People Needed }\end{array}$ \\
\hline Chrome & 20,000 & 1,065 & 19 & 1,350 & 15 \\
\hline CSB & 7,500 & 456 & 16 & 630 & 12 \\
\hline $\begin{array}{c}\text { Plywood } \\
\text { and Seri }\end{array}$ & 90,000 & 765 & 118 & 900 & 100 \\
\hline Total & 117,500 & & 153 & & 127 \\
\hline
\end{tabular}

Source: Processed Data. 
The company sets lower targets (Table 1 ) in the first two months. We realize that they need time to adapt to this work before the speed of their work is in accordance with what the company expects. It is expected that their speed would increase so that the target in the next two months and in the fifth month onwards would be normal according to the previous target value.

Based on the calculation of labor costs in the packing division, the company hopes that later the implementation of the outsourcing system can reduce labor costs lower. Furthermore, after CV HK Mojokerto's production capacity was calculated (Table 3), the labor needed (if the specification of the labor is in accordance with expectations) is approximately 127 people, or reduced by 26 from the current number.

Outsourcing is divided into 2 broad categories consisting of Business Process Outsourcing (BPO) and Human Resource Outsourcing. CV HK Mojokerto chose to use outsourcing type of Business Process Outsourcing (BPO) because the company would divert 1 division-the packing division-to the outsourcing service provider. In addition, they will be paid based on the product they are packing.

At this stage, companies need to compare the cost of outsourcing system with the old system because the implementation of the outsourcing system is expected to improve labor performance and cost efficiency. Cost efficiencies that can be done due to the implementation of outsourcing systems include salary costs that are adjusted to productivity, no premiums on BPJS Kesehatan (Social Security Administrator for Health) or BPJS Ketenagakerjaan (Social Security Administrator for Employee), no pension fees or Old Age Guarantees, there are no meal costs, and there are no fees for holiday allowances.

The estimate of company's cost efficiency that use the outsourcing system is around 145.8 million rupiah per month for 150 labors or experiencing savings of 1.75 billion rupiah a year. If it is compared between the use of outsourcing system and the current system, it is known that the use of outsourcing systems makes the company do financial efficiency because it does not pay for BPJS Kesehatan, BPJS Ketenagakerjaan, meals, and holiday allowances with a total of IDR 972,283 per person per month.

The following is the company's assumption after the packing division was transferred to the outsourcing party, with an average monthly cost per person equivalent to the Mojokerto City Minimum Wage and with an additional insurance fee of IDR 15,000 per person per month which would be IDR 3,580,000 per person people per month. Thus, the labor costs that will occur in the packing division are as follows:

Table 4 - Composition of Labor Cost Target at the Packing Division during Outsourcing

\begin{tabular}{|c|c|c|c|c|c|c|}
\hline \multirow[b]{2}{*}{$n / n$} & \multicolumn{3}{|c|}{ Current Condition } & \multicolumn{3}{|c|}{ Month 1-2 of Outsourcing } \\
\hline & Chrome & CSB & $\begin{array}{l}\text { Plywood \& } \\
\text { Seri }\end{array}$ & Chrome & CSB & $\begin{array}{c}\text { Plywood \& } \\
\text { Seri }\end{array}$ \\
\hline Labor Salary/ Month & $\begin{array}{c}\text { IDR } \\
4,537,283 \\
\end{array}$ & $\begin{array}{c}\text { IDR } \\
4,537,283\end{array}$ & $\begin{array}{c}\text { IDR } \\
4,537,283 \\
\end{array}$ & $\begin{array}{c}\text { IDR } \\
3,580,000\end{array}$ & $\begin{array}{c}\text { IDR } \\
3,580,000\end{array}$ & IDR 3,580,000 \\
\hline Labor Salary/ Day & $\begin{array}{c}\text { IDR } \\
181,491 \\
\end{array}$ & $\begin{array}{c}\text { IDR } \\
181,491 \\
\end{array}$ & $\begin{array}{c}\text { IDR } \\
181,491 \\
\end{array}$ & $\begin{array}{c}\text { IDR } \\
143,200 \\
\end{array}$ & $\begin{array}{c}\text { IDR } \\
143,200 \\
\end{array}$ & IDR 143,200 \\
\hline $\begin{array}{c}\text { Average Packing } \\
\text { Ability }\end{array}$ & 1,065 & 465 & 765 & 950 & 430 & 600 \\
\hline $\begin{array}{l}\text { Packing Labor Cost/ } \\
\text { Kg }\end{array}$ & IDR 170 & IDR 390 & IDR 237 & IDR 151 & IDR 333 & IDR 239 \\
\hline \multirow[b]{2}{*}{$\mathrm{n} / \mathrm{n}$} & \multicolumn{3}{|c|}{ Month 3-4 of Outsourcing } & \multicolumn{3}{|c|}{ Month 5 of Outsourcing Onwards } \\
\hline & Chrome & CSB & $\begin{array}{l}\text { Plywood \& } \\
\text { Seri }\end{array}$ & Chrome & CSB & $\begin{array}{c}\text { Plywood \& } \\
\text { Seri }\end{array}$ \\
\hline Labor Salary/ Month & $\begin{array}{c}\text { IDR } \\
3,580,000 \\
\end{array}$ & $\begin{array}{c}\text { IDR } \\
3,580,000\end{array}$ & $\begin{array}{c}\text { IDR } \\
3,580,000 \\
\end{array}$ & $\begin{array}{c}\text { IDR } \\
3,580,000 \\
\end{array}$ & $\begin{array}{c}\text { IDR } \\
3,580,000 \\
\end{array}$ & IDR 3,580,000 \\
\hline Labor Salary/ Day & $\begin{array}{c}\text { IDR } \\
143,200 \\
\end{array}$ & $\begin{array}{c}\text { IDR } \\
143,200\end{array}$ & $\begin{array}{c}\text { IDR } \\
143,200 \\
\end{array}$ & $\begin{array}{c}\text { IDR } \\
143,200 \\
\end{array}$ & $\begin{array}{c}\text { IDR } \\
143,200 \\
\end{array}$ & IDR 143,200 \\
\hline $\begin{array}{c}\text { Average Packing } \\
\text { Ability }\end{array}$ & 1,150 & 530 & 750 & 1,350 & 630 & 900 \\
\hline $\begin{array}{c}\text { Packing Labor Cost/ } \\
\text { Kg }\end{array}$ & IDR 125 & IDR 270 & IDR 191 & IDR 106 & IDR 227 & IDR 159 \\
\hline
\end{tabular}

Source: CV HK Mojokerto. 
Thus, even though in the first and second months the packing ability of the outsourcing company is lower than the old employee, the company still gets benefits in terms of cost per $\mathrm{kg}$ because salary costs are reduced due to the absence of benefits such as the previous contract employees. As for the calculation of savings over a period of 1 year, assuming 1 month is 25 working days multiplied by 12 months which can be calculated as follows:

Table 5 - Calculation of Benefits

\begin{tabular}{|c|c|c|c|c|c|c|c|}
\hline $\begin{array}{c}\text { Nail } \\
\text { Type }\end{array}$ & $\begin{array}{c}\text { Production } \\
\text { Capacity } \\
\text { Per Day } \\
\mathrm{kg})\end{array}$ & $\begin{array}{c}\text { Production } \\
\text { Capacity } \\
\text { Per Year }\end{array}$ & $\begin{array}{c}\text { Current } \\
\text { Cost }\end{array}$ & Total Cost & $\begin{array}{c}\text { Worst } \\
\text { Cost }\end{array}$ & Total Cost & Worst Saving \\
\hline Chrome & 20,000 & $6,000,000$ & 170 & $1,022,486,310$ & 151 & $904,421,053$ & $118,065,257$ \\
\hline CSB & 7,500 & $2,250,000$ & 390 & $878,183,806$ & 333 & $749,302,326$ & $128,881,481$ \\
\hline $\begin{array}{c}\text { Plywood } \\
\text { \& Seri }\end{array}$ & 90,000 & $27,000,000$ & 237 & $6,405,576,000$ & 239 & $6,444,000,000$ & $(38,424,000)$ \\
\hline Total & 117,500 & $32,250,000$ & & $8,306,246,116$ & & $8,097,723,378$ & $208,522,738$ \\
\hline Chrome & 20,000 & $6,000,000$ & 170 & $1,022,486,310$ & 106 & $636,444,444$ & $386,041,865$ \\
\hline CSB & 7,500 & $2,250,000$ & 390 & $878,183,806$ & 227 & $511,428,571$ & $366,755,235$ \\
\hline $\begin{array}{c}\text { Plywood } \\
\text { \& Seri }\end{array}$ & 90,000 & $27,000,000$ & 237 & $6,405,576,000$ & 159 & $4,296,000,000$ & $2,109,576,000$ \\
\hline Total & 117,500 & $32,250,000$ & & $8,306,246,116$ & & $5,443,873,016$ & $2,862,373,100$ \\
\hline
\end{tabular}

Source: Processed Data.

Thus, following the above assumptions, even though the results of the outsourcing program did not run well, or like the assumptions of months1 and 2 which were below current capacity, CV HK Mojokerto still benefited around 208 million rupiah due to cheaper labor costs. If this program can run according to the target, the savings obtained by CV HK Mojokerto are around 2.8 billion rupiah.

At this stage, the company needs to do the following steps:

- Conducting surveys to find the provider of outsourcing labor who have previously worked on similar work so that it facilitates the transition in system change;

- Conducting tender activity to find which company is the cheapest or the most suitable for the budget;

- Evaluating and discussing directly to find out the competencies and commitments of each provider of outsourcing labor, so that the trusted, honest, consistent, and easily invited provider of outsourcing labor will be selected.

Meanwhile, for the criteria of service providers, the results of management meetings for the required criteria and the weight of each criterion are as follows:

Table 6 - Criteria for Outsourcing Service Provider

\begin{tabular}{|l|c|}
\hline \multicolumn{1}{|c|}{ Criteria } & Weight \\
\hline Have license from the Manpower Office & 0.20 \\
\hline Have a competitive price & 0.15 \\
\hline Have experience in the packing field for more than 10 years & 0.12 \\
\hline Have labor according to specifications & 0.12 \\
\hline Have more than 130 members who can be allocated to CV HK Mojokerto & 0.12 \\
\hline Have a short transition time for maximum 2 months & 0.1 \\
\hline Give a beneficial compensation for CV HK Mojokerto if their performance is not good & 0.1 \\
\hline Have a minimum contract period of 2 years & 0.09 \\
\hline
\end{tabular}

Source: CV HK Mojokerto.

Based on the proposal submitted by the outsourcing company, the analysis was carried out to select which service provider would later become the partner of CV HK Mojokerto in the process of nail outsourcing division. Each service provider will be rated one to three in each category: Value $1=$ not according to requirements; Value $2=$ points must still be negotiated; Value 3 = very suitable with CV HK's needs. 
Table 7 - Rating for PT BUS Mojokerto

\begin{tabular}{|l|c|c|c|}
\hline \multicolumn{1}{|c|}{ Criteria } & Rate & Weight & Total \\
\hline Have license from the Manpower Office & 3 & 0.2 & 0.6 \\
\hline Have a competitive price & 2 & 0.15 & 0.3 \\
\hline Have experience in the packing field for more than 10 years & 3 & 0.12 & 0.36 \\
\hline Have labor according to specifications & 3 & 0.12 & 0.36 \\
\hline Have more than 130 members who can be allocated to CV HK Mojokerto & 3 & 0.12 & 0.36 \\
\hline Have a short transition time for maximum 2 months & 2 & 0.1 & 0.2 \\
\hline Give a beneficial compensation for CV HK Mojokerto if their performance is not good & 2 & 0.1 & 0.2 \\
\hline Have a minimum contract period of 2 years Total & 3 & 0.09 & 0.27 \\
\hline \multicolumn{2}{|l|}{} & 2.65 \\
\hline
\end{tabular}

Source: processed data.

Table 8 - Rating for PT KBM Sidoarjo

\begin{tabular}{|l|c|c|c|}
\hline \multicolumn{1}{|c|}{ Criteria } & Rate & Weight & Total \\
\hline Have license from the Manpower Office & 3 & 0.2 & 0.6 \\
\hline Have a competitive price & 1 & 0.15 & 0.15 \\
\hline Have experience in the packing field for more than 10 years & 3 & 0.12 & 0.36 \\
\hline Have labor according to specifications & 3 & 0.12 & 0.36 \\
\hline Have more than 130 members who can be allocated to CV HK Mojokerto & 3 & 0.12 & 0.36 \\
\hline Have a short transition time for maximum 2 months & 3 & 0.1 & 0.3 \\
\hline Give a beneficial compensation for CV HK Mojokerto if their performance is not good & 2 & 0.1 & 0.2 \\
\hline Have a minimum contract period of 2 years Total & 3 & 0.09 & 0.29 \\
\hline \multicolumn{1}{|c|}{} & & 2.6 \\
\hline
\end{tabular}

Source: Processed Data.

Table 9 - Rating for PT SKT

\begin{tabular}{|c|c|c|c|}
\hline Criteria & Rate & Weight & Total \\
\hline Have license from the Manpower Office & 1 & 0.2 & 0.2 \\
\hline Have a competitive price & 3 & 0.15 & 0.45 \\
\hline Have experience in the packing field for more than 10 years & 1 & 0.12 & 0.12 \\
\hline Have labor according to specifications & 1 & 0.12 & 0.12 \\
\hline Have more than 130 members who can be allocated to CV HK Mojokerto & 1 & 0.12 & 0.12 \\
\hline Have a short transition time for maximum 2 months & 1 & 0.1 & 0.1 \\
\hline Give a beneficial compensation for CV HK Mojokerto if their performance is not good & 1 & 0.1 & 0.1 \\
\hline Have a minimum contract period of 2 years & 1 & 0.09 & 0.09 \\
\hline Total & & & 1.3 \\
\hline
\end{tabular}

Source: Processed Data.

The maximum value that can be obtained by prospective service provider is 3 . The service provider that will be considered is the one that accumulates the rate of more than 24 or $80 \%$ of the available rate. After analysis and comparison between the three service providers, it was decided that CV HK Mojokerto would negotiate with PT BUS Mojokerto because their work costs were lower than PT KBM Sidoarjo and had a relatively short transition time.

At this stage, CV HK Mojokerto and PT BUS Mojokerto will negotiate several matters. The first is about the price per kg proposed by PT BUS Mojokerto. Even though the price per $\mathrm{kg}$ they offer is below the costs currently borne by CV HK, the costs they submit are still below the costs expected by CV HK through this outsourcing process. CV HK Mojokerto will use the price obtained from the proposal submitted by PT SKT to begin negotiations with PT BUS Mojokerto. Thus, PT BUS Mojokerto understands if there are other service providers who can provide more value to CV HK Mojokerto at a more competitive price, so PT BUS Mojokerto can reduce the price they submit.

In addition to negotiations about costs, the matters to be negotiated are issues of time of adaptation and compensation. CV HK proposed to PT BUS to cut their adaptation time to one or two months. After the third month, the compensation promised by PT BUS would proceed. 
At this stage, the company needs to do the following points:

Labors whose contracts will expire in a period of three months, totaling 50 people, remain in the packing division. After their contract expires, their contract will not be extended. CV HK Mojokerto did not terminate their contract before the contract period expired because it would later bring up other costs in the form of compensation for premature termination of contracts. Therefore, it was decided that they would continue to work until the end of their contract. In addition, by continuing to place them in the packing division, CV HK Mojokerto expected that they could provide examples to labors from PT BUS Mojokerto about how to work so far. Another reason why they are still placed in the packing division is to maintain if there are labors of PT BUS Mojokerto who do not meet the company's expectations in terms of productivity in the first three months. In other words, there are still old labors who can back up the performance of PT BUS Mojokerto.

For labors whose contract period is still long, they will be transferred to other divisions which still need additional labor. That was because CV HK Mojokerto could not terminate their contract halfway. That will cause huge costs, considering the number is 150 people. In addition, they have enough knowledge about how companies operate so that if they are transferred to another division, the transition time is not as long as the company is looking for new labors.

CV HK Mojokerto will send some expert labors in the field of nail packing to PT BUS Mojokerto a week before the cooperation contract begins. The aim is to provide lessons or knowledge transfer to PT BUS Mojokerto so that they can prepare their labors who will be placed in CV HK Mojokerto to work on nail packing.

During the transition time, CV HK Mojokerto will later place several old labors to help PT BUS Mojokerto employees in the early months. Thus, difficulties they experience can be helped by old employees who already have experience in nail packing.

At this stage, the company needs to do the following points:

Conduct monthly meetings so that both parties can express their expectations. This meeting is an evaluation material for improvement and planning for the following months.

Keep each other's commitment to continuously work according to the agreed contract or agreement.

Based on the research findings, planning on the outsourcing system of packing division at CV HK Mojokerto can be concluded as follows:

Table 10 - Planning on the Outsourcing System of Packing Division at CV HK Mojokerto

\begin{tabular}{|l|l|}
\hline Stage 1: Planning & $\begin{array}{l}\text { CV HK Mojokerto determined the packing target of the outsourcing system and the } \\
\text { amount of labor that must be provided by the outsourcing service provider }\end{array}$ \\
\hline $\begin{array}{l}\text { Stage 2: Strategy } \\
\text { Selection }\end{array}$ & $\begin{array}{l}\text { CV HK Mojokerto chose to use the Business Processing Outsourcing type and } \\
\text { restructure the packing division }\end{array}$ \\
\hline Stage 3: Cost Analysis & $\begin{array}{l}\text { CV HK Mojokerto made projections of costs for the worst and best results and } \\
\text { compared with current costs }\end{array}$ \\
\hline $\begin{array}{l}\text { Stage 4: Partner } \\
\text { Selection }\end{array}$ & $\begin{array}{l}\text { CV HK Mojokerto conducted tender activity to several service providers with criteria } \\
\text { such as: price, experience, labor skills, compensation, and length of contract }\end{array}$ \\
\hline Stage 5: Negotiation & $\begin{array}{l}\text { CV HK Mojokerto negotiated with PT BUS Mojokerto related to price, transition time, } \\
\text { and compensation to get the best deal }\end{array}$ \\
\hline $\begin{array}{l}\text { Stage 6: Human } \\
\text { Resource Transition }\end{array}$ & $\begin{array}{l}\text { CV HK Mojokerto would provide training to employees of PT BUS Mojokerto a week } \\
\text { before starting work. Employees whose contract period is still long will be transferred to } \\
\text { another division. }\end{array}$ \\
\hline Stage 7: Management & $\begin{array}{l}\text { CV HK Mojokerto and PT BUS Mojokerto will conduct meetings every month to ensure } \\
\text { that everything runs according to expectations. }\end{array}$ \\
\hline
\end{tabular}

\section{CONCLUSION}

Based on the results of the analysis and discussion of the design of the implementation of the outsourcing system of packing division in CV HK Mojokerto, it can be concluded as follows:

The company's motive in applying an outsourcing system is due to the current increase in regional minimum wages that is no longer in line with the performance in the field which 
results in higher production costs and labor performance has not achieved the target optimally. The outsourcing system is chosen because the packing work is not the company's core business. Therefore, it does not really need labors with high competence since it is more concerned with efficiency, neatness and speed. Based on the design results at each outsourcing stage, it is concluded that:

- At the planning stage, the company needs to set the target for packing results and the desired number of packing targets;

- At the strategy selection stage, the company chose to use outsourcing with Business Process Outsourcing. It means that the company hands over 1 part of the process to the third party. Furthermore, the company compiled changes to the organizational structure by including outsourcing providers and moving employees whose contracts were still running;

- At the cost analysis stage, the company needs to compare the cost of outsourcing systems with the old system. It is concluded that the selection of outsourcing systems made the company only pay labor costs according to productivity and the cost of insurance costs of IDR 15,000 per person per month. Other costs are also calculated if the results of outsourcing do not match expectations and vice versa;

- At the stage of partner selection, the company conducts tender activities to find out outsourcing labor provider which is followed by evaluation;

- At the negotiation stage, the company negotiates the scope of work and the cost per $\mathrm{kg}$, the transition time and compensation from the service provider;

- At the human resource transition stage, the company needs to conduct intensive training and control in the first three months

- In the relationship management stage, the company needs to conduct monthly meetings as evaluations for improvement and planning in the following months.

\section{REFERENCES}

1. Elmuti, D. (2003) 'The Perceived Impact of Outsourcing on Organizational Performance', American Journal of Business, Vol.18 Iss 2, pp. $33-42$.

2. Indrajit, R.E., and Djokopranoto, R. (2004) Proses Bisnis Outsourcing. Jakarta: Penerbit Grasindo.

3. Kremic, T., Tukel, O.I., and Rom, W.O. (2006) 'Outsourcing decision support: a survey of benefits, risks, and decision factors', Supply Chain Management: An International Journal, Vol. 11 No. 6, pp. 467-482.

4. Miles, Matthew B., and A. Michael Huberman. (2005). Qualitative Data Analysis. (terjemahan). Jakarta: UI Press.

5. Moleong, L.J. (2010) Metodologi Penelitian Kualitatif. Bandung: Remaja Rosda Karya.

6. Pratap, S. (2014) 'Towards a framework for performing outsourcing capability', Strategic Outsourcing: An International Journal, Vol. 7 Iss 3, pp. $226-252$.

7. Sugiyono. (2013) Metode Penelitian Kuantitatif, Kualitatif and R\&D. Bandung: Penerbit CV. Alfabeta.

8. Sutrisno, E. (2009) Manajemen Sumber Daya Manusia. Edisi pertama. Jakarta: Kencana Prenada Media Group. 